\title{
硬質塩化ビニル板のシャルピー衝撃破面につレて*
}

林 英 雄** 植 村 幸 生**

\section{Fracture Surface of Charpy Impacted Rigid PVC Plate Specimens}

by

\author{
Hideo Hayashi and Yukio Uemura \\ (Government Industrial Research Institute, Osaka)
}

The Charpy impact value of plastics is greatly influenced by the notch shape of test specimens. And there exists a close correlation between the Charpy impact value and the appearance of the fracture surface. In this paper, the relation between the notch shape and the appearance of the fracture surface of rigid PVC plates was studied.

The results obtained are summarized as follows:

(1) The fracture of the Charpy impact test specimens did not originate from the surface of notch root, but starts from the inside below the notch root.

(2) The distance between the notch root and the fracture origin increased with the radius of notch root, but it was not affected by the notch depth.

(3) In the case of $U$ notch $(r=1.0 \mathrm{~mm}, d=2.0 \mathrm{~mm})$, the surrounding neighborhood of the fracture origin formed a sphere-like or disk-like void of about $50 \mu \mathrm{m}$ in diameter.

(Received June 11, 1977)

キー・ワード：シャルピー衝撃試験，硬質塩化ビニル板，衝撃破面

\section{1 まえがき}

プラスチック材料の場合, 試験片の切欠き形状がシ ヤルピー衝撃值に非常に大きな影響を及ぼすこと，そ して衝撃値の大きさ試験片の破断面の状態との間に は密接な関連のあることについては,すで筆者のう らの一人が報告した。

本報では，硬質塩化ビニル板のシャルピー衝撃値に 及ぼす切欠き形状の影響を求める実験に用いた試験片 の破面観察，とくにSEM 観察によって得られた知見 について報告する.

\section{2 試料およびシャルピ一衝擊試験条件}

使用した硬質塩化ビニル板は, JIS 1 種 1 号で, カ レンダシートからのプレス成形板, 外観はグレー, 板 厚約 $5 \mathrm{~mm}$ のものである. シャルピー衝撃試験条件の 詳細は既報のと和りであるが，主要事項は次の上うで ある. 用いた試験片形状を Fig. 1 に示寸. とのV形 切欠きの先端半径 $r$ 0 2.0 mm の範囲で, また切 欠き深さ $d$ を 0.1 5.0 mm の範囲でそれぞれ変化さ せた.ささら $r=1.0 \mathrm{~mm}$ のU形切欠き試験片につい

* 原稿受理 昭和52年 6 月 11 日

** 正 会員 工業技術院大阪工業技術試験所 池田市緑丘

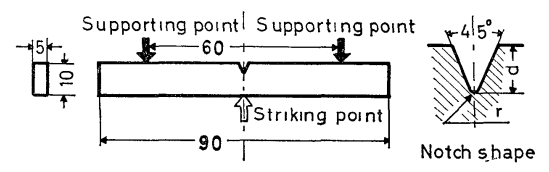

Fig. 1. Shape of test specimen.

ても同様の実験をした. 打撃速度は $2.9 \mathrm{~m} / \mathrm{s}$, 試験温 度は20すである。

\section{3 破 面 観 察}

破面観察は 2 項で述べた試験片（試料 I）の破断片 の破断面を中心に行ったが，補足的に他の同様な実験 に用いたほ注同品質の硬質塩化ビニル板製試験片（試 料 II）の破断片のそれについても行った.

\section{$3 \cdot 1$ 巨視的（肉眼的）観察}

試験片の破断面の代表例を Fig. 2 と示す.（a)は破 断側面で，(b)，(c)は相対する破断面である.

既報でる述べたように，一般にシャルピー衝撃値が 大きくなるほど破断面の荒れ具合はひどくなる，とこ ろで，その破断面を子細に観察すると，Fig.2 (b)，(c) のように，破壊は切欠き底から始まっているのではな く，切欠き底よりやや内側へ入ったところから始まっ 


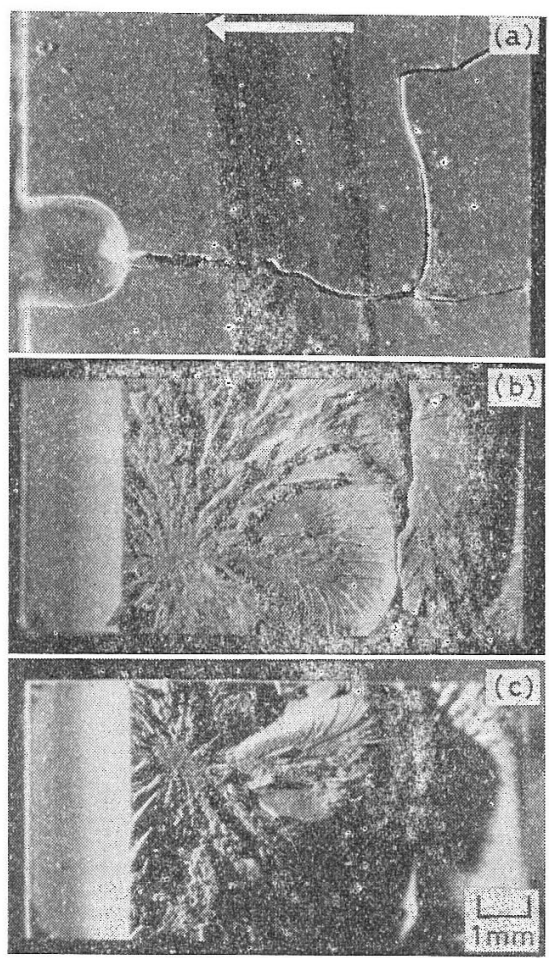

(a) Side view of fractured specimen.

(b) and (c) Matching fracture surfaces.

Slender arrow, in Figs. 2,5,7,8,9 and 11, shows striking direction.

Fig. 2. A typical fracture surface, $U$ notch $(r=$ $1.0 \mathrm{~mm}, d=2.0 \mathrm{~mm}$ ), sample $\mathrm{I}$.

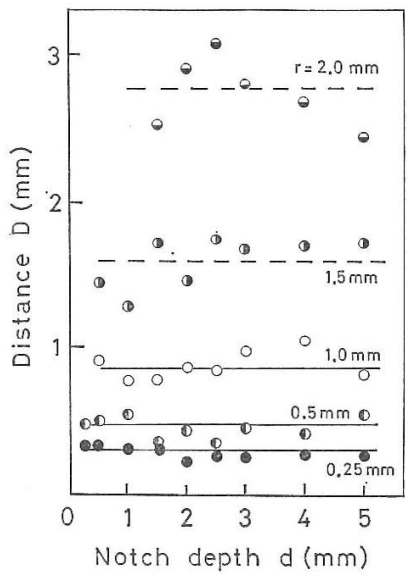

Fig. 3. Relation between notch depth, $d$, and the distance, $D$, from notch root to fracture origin.

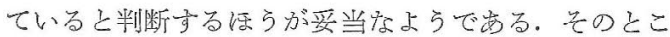
万仮に「破壤開始点」と名付ける。切久き底から破 壞開始点承での距離と，切欠き形状との関係を Fig. 3 および 4 に示す。この距離は，切欠き先端半径 $r$ の增 加ととるに增加するが，切欠き深さdの影響依㾁とえ と゚受けないよらで㐫。

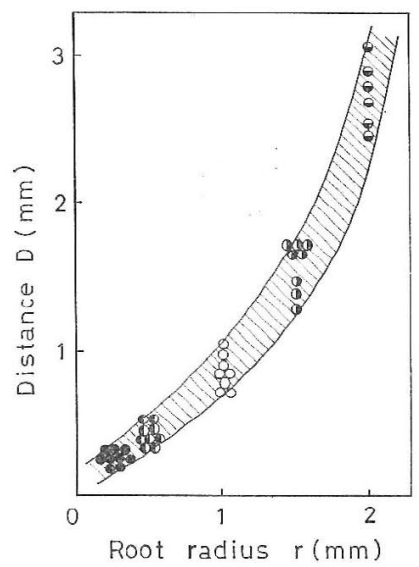

Fig. 4. Relation between radius of notch root, $r$, and the distance, $D$, from notch root to fracture origin.

\section{$3 \cdot 2$ 微視的 (SEM) 観察}

破壊開始点が切欠き底にではなく，乞こより内側に 入った位置によると考学ることの妥当性学確認するれ め，破壞開始点付近の破面の様子を SEM 学用いた站 体写真法により観察した。っここでは代表例として，慣 用のU形切欠き $(r=1.0 \mathrm{~mm}, d=2.0 \mathrm{~mm})$ 和よび JIS 規定の V 形切欠き $(r=0.25 \mathrm{~mm}, d=1.0 \mathrm{~mm})$ の場合 について述べる1

$3 \cdot 2 \cdot 1$ U形切欠さ Fig. 5 にU形切欠きの場合 の破壞開始点付近の典型例（試料II）学示す。 Fig.5 はステレオ・マッチング写真で, これから破壊開始点

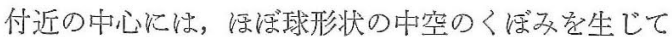
いることがわかる。そしてそのくぼみの内面には微粒 艻一面に付着している。

そこでなせ破㵙開始点付近の中心にこのような中 空のくぼみ学生じるのか教てみる.Fig.6 (a)の上う な切欠き部に引張力が作用すると，切久き部近傍は $\sigma_{x}$ ， $\sigma_{y}$ 乱よび $\sigma_{z}$ の作用する複杂倠な 3 軸広力状態になり， 平均応力 $1 / 3\left(\sigma_{x}+\sigma_{y}+\sigma_{z}\right)$ 趸生じるが，この平均応 力が最大になる位犆は助欠き底ではなく，切欠き底よ りいくらか内側のところであるとされている。このこ と老考慮して判断すると，上記破壞開始点付近は平均 応力が最大になる場所に対応し，矢の付近に存在する 添加材の之ころから破壊が開始したものと考学ること ができる。ひとたび破壊が始まると，急激な变形過程

*1 用いた硬質塩化ビニル板の場合，てれらの切欠き形状では，破断 片をつなぎ合わせると完全に元どおりの形状になり，巨視的な塑 性恋形は認められず，完全ぜい性破断しているる゙。

*2 用いた硬質塩化ビニル板の組成，性質などはおおよそ次の上うで ある。

(1) 添加材滑材 : 0.5\%, 着色材 : 3\%, 安定材 : 2\%, 紫 外線安定材气劣化防止汸：196以下.

(2) 染的性斦 JIS 軟化点温度：約 $75^{\circ} \mathrm{C}$, 約 $300^{\circ} \mathrm{C}$ 以上で分解し $\mathrm{HCl}$ ガスを発生 

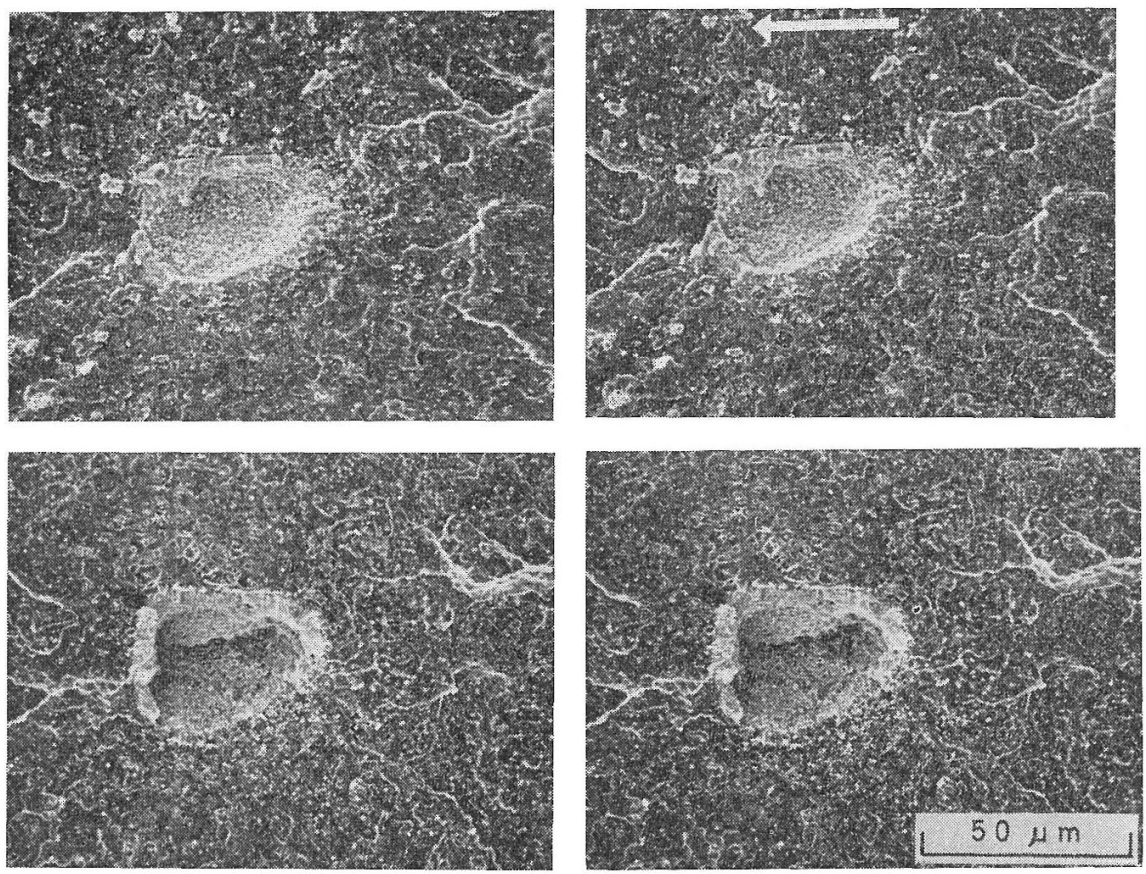

Fig. 5. SEM stereo matching pair micrograph $\left(5^{\circ}\right.$ tilt $)$ of fracture origin, $U$ notch $(r=$ $1.0 \mathrm{~mm}, d=2.0 \mathrm{~mm}$ ), sample II.
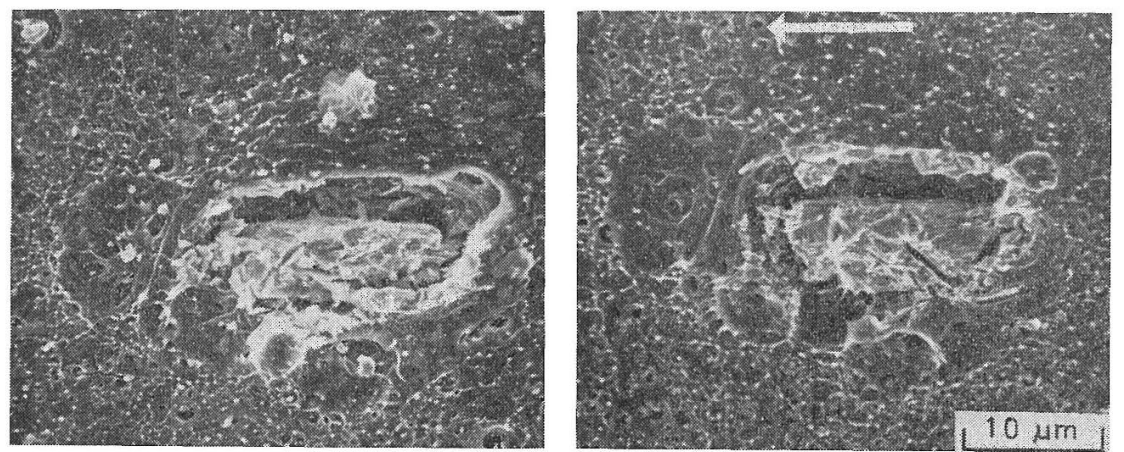

Fig. 7. SEM matching pair micrograph of fracture origin, $U$ notch $(r=1.0 \mathrm{~mm}, d=2.0$ $\mathrm{mm}$ ), sample I. Notice that additives are not dispersed.

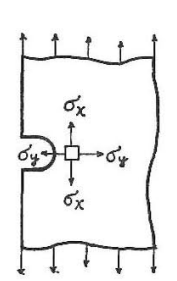

(a)

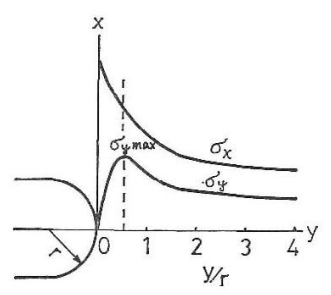

(b)
Fig. 6. Schematic stress distribution at notch root.

にあるたる゙, 内部摩擦による発熱を生じ，試験片のご く一部では軟化するだけでなく，さらに分解・気化る 起りらると考えられる。破壞開始点の中心部にみられ

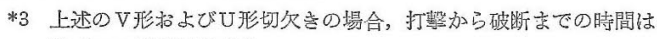
約 $1 \mathrm{~ms}$ 前後である゙).
る上記中空のくぼみはこうして生じ，ここを中心に放 射状に破欋が進行し，試験片は破断したものと判断さ れる。

Fig.5 のくぼ少の内面にみられる微粒は，破壊開始 点の山心付近ではとくに発熱が著しいので，軟化した 部分が引張力を受け，むたか子水飴状に杂至引いたよ らに引張られ，この糸が破断し凝固する際表面張打に より丸くなり，くぼみの内面に付着したるのと考觉ら れる。

破壞開始点がこのよらにして生じるとして，Fig.3 和よび4の実験結果，すなるら切欠き底加ら破壊開始 点季での距離は, 先端半径 $r$ と妇に增加するが, 切 欠さ深さdの影響は㴗とんど受けないことについて考 察してみる。シャルピー衝撃試験片の 3 点曲げのよら 

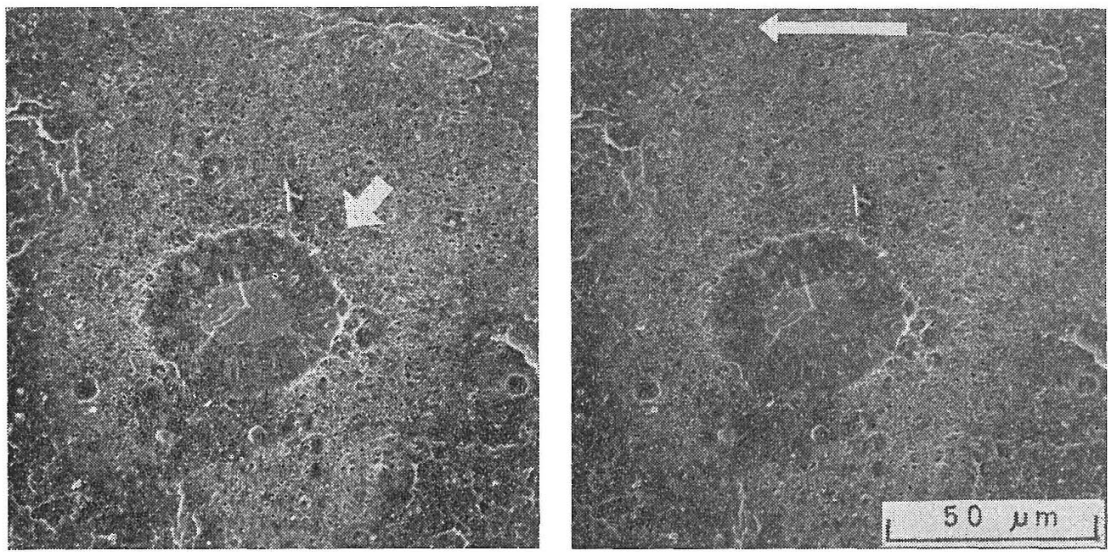

Fig. 8. SEM stereo pair micrograph $\left(5^{\circ}\right.$ tilt $)$ of fracture origin. This fracture origin is located on the fracture surface presented in Fig. 2 (c). Solid arrow indicates area presented in Fig. 9.
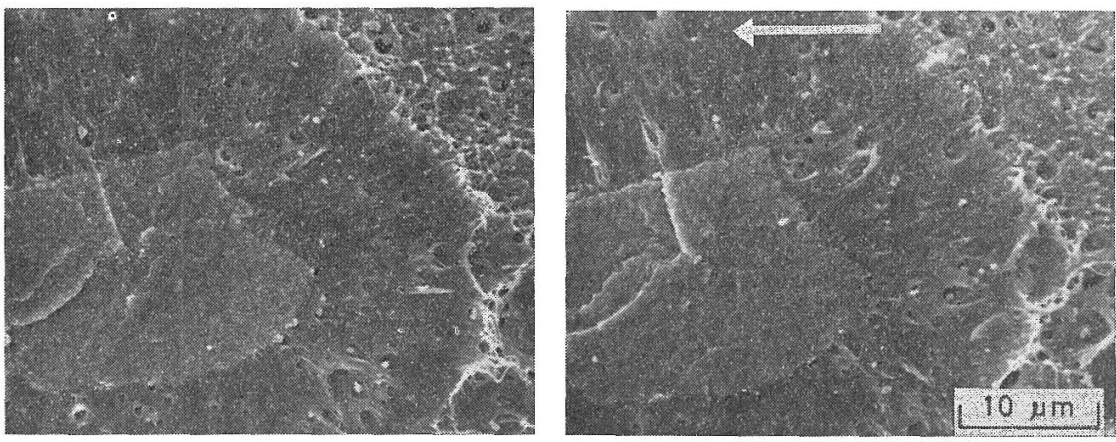

Fig. 9. Detailed view of fracture origin, matching pair micrograph, presented in Fig. 8.

な場合の切欠党部の応力分布状態は定量的にはなだ活 とんど解明されていないので，U形切欠きをるつ半無 限板に引張力が作用したときの応力分布状態を参考に 乙定性的に考光る.模式的に書けば切欠き底近傍の $\sigma_{x}$, $\sigma_{y}$ の分布は Fig.6 (b)の上らになる。この $\sigma_{y}$ 最大の 位置は，r/d の值が小さいときには切欠き底に接近す

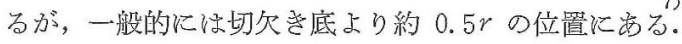
すなわち， $\sigma_{y}$ 最大の位置は切欠き深さ $d$ 上りる先端 半径 $r$ 強く依存する. このことはをた, 切欠き底近 傍の応力分布状態の特徵は深さd $d$ 上る先端半径 $r$ 飞 強く支配されることを意味する。これらの特徴は曲牧 学受ける切欠きの場合でる，添济同様と考光られる。 応力分布状態の特徵から, 平均応力の最大値は $\sigma_{y}$ の 最大值付近住じるものと考光られるので, 破懷開始 点の位䈯は先端半径 $の$ 影響を強く受けるが, 深さd には西告関係しないことになると思われる。

最車型的なくぼるが Fig. 5 であるが，この外化も

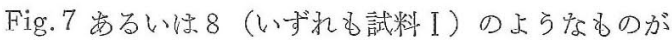
みられる。いずれの場合る，平均応力が最大湾なる付 近にたまたま前述の添加材のかたまりが步り，そこか ら破懐が始をったるのと考克られる。両者の破面状態 がやや異るのは，添加材の性質の差によるるのでるる。

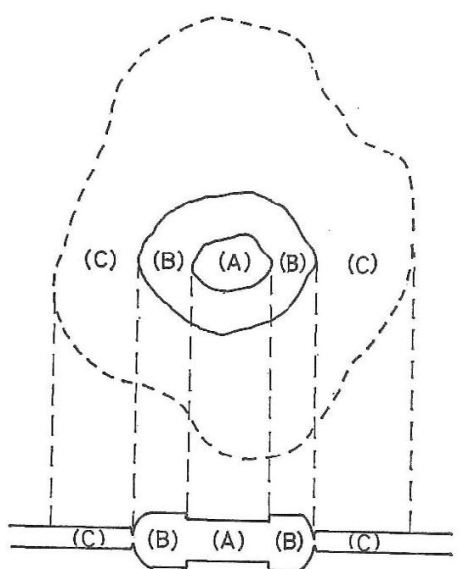

Fig. 10. Schematic diagram of fracture origin presented in Fig. 8.

すなわち，一方が硬ぜい質（Fig.7 の場合）であるの に封し，他方がモルタル状質 (Fig. 8 の場合) で㐫る ためで岁るFig.8 は Fig.2 (C)飞示した破断面のる ので，Fig. 9 はその一部を拡大したもの，をたFig.10

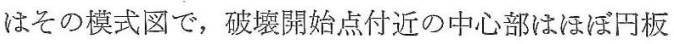
状の中空のくぼるになっている。(B)部には放射状にか なり大きなディンプルがみられ，(C)部には(B)部に比べ 

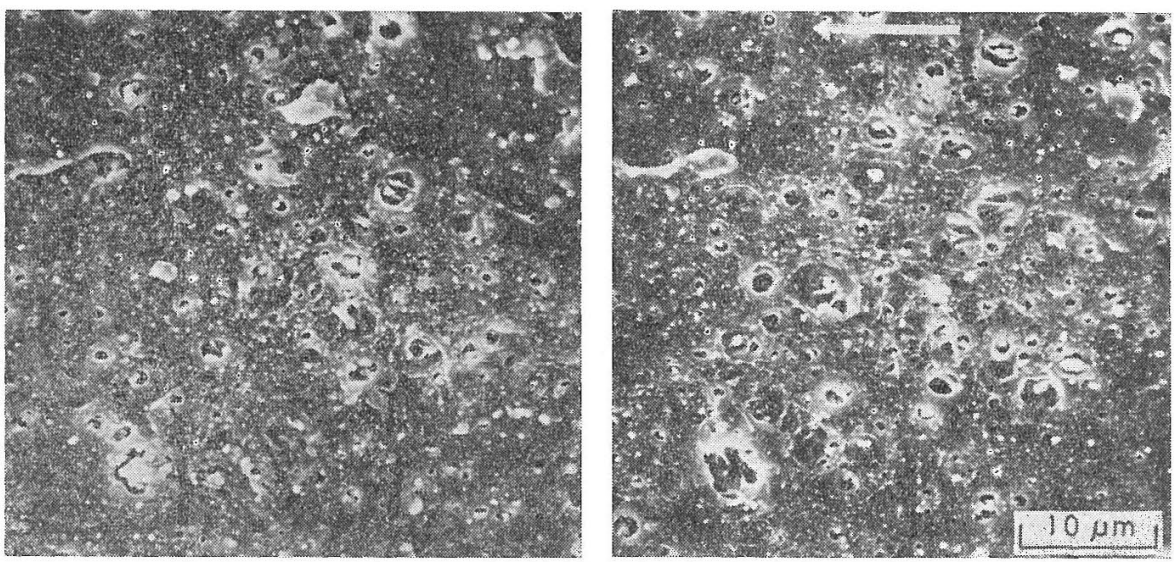

Fig. 11. SEM matching pair micrograph of fracture origin, $V$ notch, $(r=0.25 \mathrm{~mm}$, $d=1.0 \mathrm{~mm}$ ), sample $\mathrm{I}$.

密なディンプルダ存在する.Fig.8のくばみの場合， Fig. 5 の場合と異り，Fig. 10 で表されるようなくぽ 又になったのは，次の上うに考壳られる。破填の開始

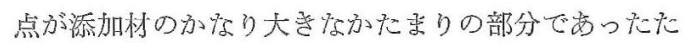

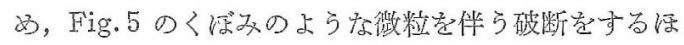
ぞ温度上开いしはいが，かなりの発熱索伴らため顿化 点前後索では温度上昇する。このため(B)部には大きな ディンプルが発生するし，先の破断面はかなり滑らか なるのとなる。(C)部になると温度上昇が少いので軟化 点より低く，塑性変形はしやすくなってはいるものの (B)部添ど大きな変形はしない孞め, 密なディンプルを 多数発生したもの之持光られる。

以上のよう飞破壤開始点付近には, 中空の球形状㐫 るいは円板状のくぼみ赏生じているが，いずれるとの

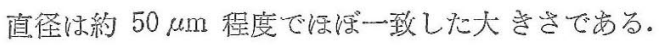

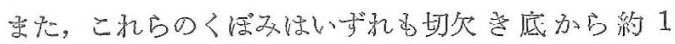
$\mathrm{mm}$ 前後のところにある。

$3 \cdot 2 \cdot 2 \mathrm{~V}$ 形切欠さ（試料 I) V V 形切欠文の場 合は，上述したU形切欠きの場合飞比べ，破断寸前の たわ文が少く，吸収エネルギす少く。したがって破断 時の発生熱量も少いので, Fig. 11 に示したように, 添加材個々のところでディンプル状のすのが多数発生 しただけで，前述のような空孔の発生に皂ではいたら ず，この付近を中心にして四方へ破壞が進行していき， 破断したるの上考完られる。

\section{4 むす び}

硬質塩化ビニル板のシャルピー衝撃試験片の破壊用
始点は, 切欠き底ではなく, 破偯は切欠き底上り内側 に入ったところから発生していること，允して切欠き 底より破壤開始点采での距離怯, 切欠き先端半径とと ると增大するが，切火き深さの影響は泟とえど受けな いことを明らかてした。またU形切欠丞 $(r=1.0 \mathrm{~mm}$, $d=2.0 \mathrm{~mm}$ ) の場合には, 破噮開炲点の中心部に, 直 径执上先 $50 \mu \mathrm{m}$ 程度の球形状むたは円板状の空孔定 生じていることを見いだした。

本研究をすす西るにあたって，いるいるとご教示， ごべんたつをいただいた大阪大学工学部中川憲治教授, 東京大学生産技術研究所北川英夫教授, 大阪大学基礎 工学部小寺沢良一助教授和よび茨城大学工学部增田雄 市郎氏に厚く特礼申し上げます。

（昭和52年5月26日 日本材料学会第1回フシクトグラフィシンポジウ 幺汇て讙演)

\section{参考文 献}

1) 植村幸生, 日本機栈学会論文集, 39, 1203 (1973).

2) 植村幸生, 日本機械学会論文論，39，2975 (1973)。

3) 植村幸生, 日本機械学会論文集, 40, 2161 (1974)。

4) 植村幸生, 日本機械学会瀞演論文集, 773-1，40（1977）.

5) Boyd, G. M., Engineering Fracture Mechanics, 4, 459 (1972).

6) 中沢 一，小林烡男，“固体の強度”， p. 183 (1976) 共 立出版

7) 西田正萗, “応力集中”, p. 586 (1967) 菻北出版 